\title{
「花火」の描画手法にみる事象の知覚と表現
}

\author{
絵画の表現技法の言語記述と分類に関する予備的検討 \\ ○鈴木清重 \\ (東の森映画製作所・慶應義塾大学法学部, 商学部) \\ キーワード : 知覚と表現、事象知覚、視覚的表現と言語行動
}

Event perception and expression in the drawing technique of "fireworks".

Kiyoshige SUZUKI

(Higashinomori Film Studio, Keio University)

Key Words: perception and expression, event perception, visual expression and verbal behavior

\begin{abstract}
目 的
花火の絵画は、花火の知覚の樣態を検討可能にすると考え られる（増田・鈴木 ・ 増田, 2006; 鈴木 ・増田, 2008)。増田 ら（2006） は美術系の学生に「花火の描画」を求める予備調 查を実施し、120 枚の絵画作品を花火の知覚内容に基づき 4 種類 (平面: 51 、立体: 99、抽象: 23 、事象: 11 枚、重複: 64 ) に分類した。分類結果は調查対象者の「花火」の画が調查対 象者の日常的な花火(爆発物)の知覚を反映する可能性を示唆 した。絵画の内容と描画手法は、爆発物の知覚に限らず私た ちの日常的な事象知覚の样態を反映する可能性がある。

予備調查（増田・鈴木・増田, 2006 他）には、知覚内容の 検討材料となるカテゴリーごとの絵画作品の特徴が一意に確 定しない問題があった。 1 枚の画が複数の描画手法と知覚内 容を含み、作品の分類に重複があっためである。鈴木 (2017) は、分類カテゴリーと作品を一意に対応させる手続きで新し い分類基準を作成した。予備調查データの分類を追試した結 果、予備調查と同様の分類（平面、立体、印象、事象）が可 能であった。各分類名に該当する作品の典型例に変更はなく、 予備調查と追試の結果の一致率は $76 \%$ であった。しかし、鈴 木（2017）の分類基準を用いた 2 名の分類者による追試結果 の一致率は $27 \%$ であり、分類基準の信頼性に問題が残った。

本研究の目的は、1) 鈴木 (2017) が作成した絵画の分類 基準を改良することである。異なる分類者間で一致率が高く、 信頼性の高い分類基淮を検討する。視覚的表現を言語により カテゴリー分類する上での問題点を検討し、2）新しい分類 基準により、予備調查の結果を再検討する。
\end{abstract}

\section{方 法}

調査対象 デザイン、美術の専門学校と大学へ通う 18 歳 から 25 歳の男性 3 名、女性 117 名であった（平均 18.7 歳、 土標準偏差 1.1 、以下同じ)。美術教育を受けた年数は平均 $4.0 \pm 3.0$ 年であり、最頻値は 6 年であった。 1 年に花火を見 る回数は平均 $2.3 \pm 3.3$ 回であり、最頻值は 1 回だった。

材料 描画用に、B 5 版のコピー用紙を用いた。調查対象 者が普段学校へ持参し使用する筆記用具、画材を自由に使用 するよう求めた。

手続き 2006 年 5 月に都内で 3 回に分けて実施した。デザ イン、美術系の専門学校および大学の 3 つの講義の冒頭で用 紙を配布した。以下の教示を板書と口頭で与えた「花火の画 を描いてください。10 分間」。所要時間は、15２0 分だった。

結果の処理 映像制作経験のある 46 歳の男性 1 名が調查 対象者の絵画作品を観察し、鈴木（2017）に基づくカテゴリ 一に分類した (分類 $\mathrm{A}$ )。分類に際して分類基準を作成した。 完成した分類基準を用いて、デザインの専門教育を受けた 29 歳の女性 1 名が分類作業を行った (分類 B)。2 2 つの分類結果 の一致率を算出し、絵画表現のカテゴリー分類基準の問題点 を検討した。

\section{結 果}

分類 $\mathrm{A}$ により新しい分類基準を作成した。分類 $\mathrm{A}$ の結果、 120 枚の絵画作品を鈴木（2017） と同様の 4 種に分類（平面： 9、立体：63、印象：33、事象：15 枚、重複なし) できた。 予備調查（増田・鈴木・増田，2006; 鈴木・増田，2008）お よび鈴木（2017）が各分類の典型例と考えた作品の分類結果 に変更はなかった。予備調查との一致率は $79 \%$ であった。分 類 B の結果、分類 $\mathrm{A}$ と同様の 4 種に分類 (平面：11、立体 : 73、印象：17、事象：19 枚、重複なし) できた。典型例の分 類結果は予備調查から変更がなく、予備調查との一致率は $76 \%$ であった。分類 $\mathrm{A}$ と分類 $\mathrm{B} の 一$ 致数は、平面：3、立体：49、 印象：13、事象：10枚であり、合計 75 枚が一致した（一致 率 $64 \%$ )。予備調查から全ての分類結果を通じて典型例 4 枚 (鈴木・増田, 2008 他)の分類結果の一致率は $100 \%$ だった。

\section{考 察}

予備調查との一致率より新しい分類基準は妥当だったと考 えられるが、分類 A、B 間の一致率より信頼性に問題があった。 平面と立体の表現を弁別する難しさと個人差が要因の 1 つと 考えられる。画像と言語行動の対応を検討する必要がある。

描画手法と事象知覚の関係を考察した。「平面」の描画手法 の典型例は花火を平面 (円、丸) の火花の配置として描く特 徵をもち、地上からの爆発物の知覚経験を反映したと推測で きる。「立体」の描画手法の典型例は花火を立体（球体）の火 花の配置として描く特徵をもち、TV 中継（空撮）による爆発 物の知覚経験を反映したと推測できる。印象」の描画手法の 典型例は爆発の印象もしくは爆発事象に接近した様子を描く 特徵をもち、花火の局所的部分の凝視する知敩経験を反映し たか、爆発の印象を反映したと推測できる。「事象」の描画手 法の典型例は、「爆発後の煙が漂う空」を描く特徵をもち、花 火を鑑賞した直後の風景を描いたと推測できた。制作者自身 の言語報告より、毎年花火大会を鑑賞した直後に観察する風 景を描いたとのことであった。モノとしての花火を描かず、

「花火の体験」を描き花火を表現する手法は、動画像編集な ぞの視覚表現に共通寸る技法と考えられる。みかけの画像系 列に非感性的完結化を生じさせる技法と考えられる。

\section{引用文献}

増田 知尋・鈴木 清重・増田 直衛（2006）。打ち上げ花火は ぞう見える? 一拡大運動の知覚一日本アニメーション学 会第 8 回大会 沖縄県立芸術大学

鈴木 清重・増田 知尋 (2008). 外界の「うごき」にみるアミ ユーズメント一表現と認識一 村上 和夫・長田 佳久・河 東田 博（編）たのしみを解剖する:アミューズメントの 基礎理論（pp. 30-59）現代書館

鈴木 清重 (2017).「花火」の描画手法に関する実証的研究 日 本基䃈心理学会第 36 回大会 立命館大学 